\title{
Opening Remarks by Pedro Comissário Afonso
}

A most warm welcome to the first panel of the event celebrating the seventieth anniversary of the International Law Commission. I was given this rare privilege and responsibility of presiding over the first panel of a total of five, to be held under the theme: "Seventy Years of the International Law Commission: Drawing a Balance for the Future". I wholeheartedly thank the members of the Commission and, in particular, Professor Georg Nolte, Chair of the International Law Commission at its sixty-ninth session, for this honour bestowed upon me and for their trust.

In these brief remarks, I would like to recognize and introduce my distinguished colleagues in the panel, namely, Alejandro Rodiles, Professor of International Law and Global Governance at the Instituto Tecnológico Autónomo de Mexico, School of Law, in Mexico City; Laurence Boisson de Chazournes, Professor of International Law at the University of Geneva; and Mr. Pavel Šturma, Professor of International Law and member of the International Law Commission.

The topic of panel 1 is "The Commission and its impact". The members of the panel will discuss issues that are well known. Among those issues are the following: 1) What happens to the final products of the International Law Commission?; 2) What has been the impact of the work of the Commission on State practice, jurisprudence of international courts and tribunals and legal scholarship?; 3) To what extent does the form of the work of the Commission affect its impact?

After having heard many important and inspiring statements at the solemn meeting, we are very fortunate to have these three speakers with us today. Professor Rodiles will speak on the topic "The International Law Commission and change: Not tracing but facing it". Professor Boisson de Chazournes will expound on the theme "The International Law Commission in a Mirror - Forms, Impact and Authority".

The celebration of the sevenieth anniversary of the International Law Commission is a momentous event. It is an opportunity for us to pause and reflect on the centrality of international law in today's international relations. In this chamber, we have come from different walks of life. For some of us, who have been following law and diplomacy for almost 40 years, there is an obvious lesson that we can draw from the Charter of the United Nations. It is the notion that even sovereignty needs law; internally, to function properly and with 
fairness, and at the international level, to co-exist and cooperate with other competing sovereignties.

This is to say that law, and for that matter, international law, is an important source of order of international order and justice. This has been shown very clearly in a fine book entitled "Peace through International Law - the Role of the International Law Commission", edited by Professor Georg Nolte as a result of a colloquium marking the sixtieth anniversary of the International Law Commission. ${ }^{1}$

I am convinced that many of the insights and conclusions from that book are as relevant today as they were ten years ago. The world will continue to need, for many years to come, this important body that we call the International Law Commission and that is at the core of today's international rule of law. It is my sincere hope that all of us in this room will offer an active and constructive participation in the debate of the topics of our panel.

1 Georg Nolte (ed), Peace through International Law: The Role of the International Law Commission. A Colloquium at the Occasion of its Sixtieth Anniversary (Springer 2009). 